\title{
Pengaruh Perendaman Daun Jambu Biji Kering (Psidium Guava L) terhadap Kadar protein, Vitamin A dan Sensori Tahu
}

\section{Effect of Soaking Dried Guava Leaves (Psidium Guava L) on Tofu Protein, Vitamin A and Sensory Levels}

\author{
Wanti Dewayani, Riswita, Harti, Nur Fitriani Usdyana Attahmid dan Mursida \\ Balai Pengkajian Teknologi Pertanian Sulawesi Selatan \\ J. Perintis Kemerdekaan KM 17, Makassar \\ wanti.abid@gmail.com
}

\begin{abstract}
Abstrak
Tahu merupakan makanan favorit masyarakat sehari-hari. Namun tahu hanya bertahan satu hari saja, sehingga dibutuhkan pengawet untuk memperpanjang masa simpan. Salah satu pengawet alami yang potensial adalah daun jambu biji. Tujuan penelitian ini adalah untuk mengetahui pengaruh perendaman daun jambu biji kering terhadap kadar protein, vitamin A dan sensori tahu. Penelitian ini dilaksanakan pada bulan April-Mei 2019, di Laboratorium pasca panen BPTP Sulawesi Selatan. Rancangan yang digunakan adalah rancangan acak lengkap dengan perlakuan lama perendaman selama 0 hari, 2 hari, 4 hari, 6 hari, 8 hari dan 10 hari dan masing-masing perlakuan diulang tiga kali. Hasil penelitian menunjukkan bahwa perendaman tahu ke dalam ekstrak daun jambu biji (Psidium guava L) tidak berpengaruh nyata terhadap kandungan protein tahu. Perendaman tahu ke dalam ekstrak daun jambu biji berpengaruh nyata terhadap kandungan vitamin A dan sensori tahu. Perlakuan terbaik adalah tahu yang direndam dalam ekstrak daun jambu biji selama 4 hari dengan kadar protein $10.31 \%$, vitamin A $168 \%$, warna 2,67 (agak suka), aroma 3.4 (agak suka), rasa 3.07 (agak suka) dan tekstur 2.93 (agak suka).
\end{abstract}

Kata kunci : daun; daya simpan; jambu biji; kedelai; tahu

\begin{abstract}
Tofu is a favorite food of everyday people. But tofu only lasts one day, so preservatives are needed to extend the shelf life. One potential natural preservative was guava leaf. The purpose of this study was to determine the effect of soaking dried guava leaves on levels of protein, vitamin A and sensory of tofu. This research was conducted in April - May 2019, in the post-harvest laboratory of AIAT South Sulawesi. The design used was a randomized complete design with soaking duration treatment for 0,2 days, 4 days, 6 days, 8 days and 10 days and each treatment was repeated three times. The results showed that soaking tofu into guava leaves extract (Psidium guava L) did not significantly affect the content of tofu protein. Soaking tofu into guava leaves extract significantly affected the content of vitamin $A$ and sensory of tofu. The best treatment of tofu that was soaked in guava leaves extract for 4 days with protein content of $10.31 \%$, vitamin A 168\%, color 2.67 (rather like), aroma 3.4 (rather like), taste 3.07 (rather like) and texture 2.93 (rather like).
\end{abstract}

Keywords: guava; leaf; tofu; soy; storability 


\section{PENDAHULUAN}

Kedelai merupakan tanaman polong-polongan yang banyak dimanfaatkan oleh manusia untuk memenuhi kebutuhan terutama sebagai bahan dasar poduk olahan kedelai. Salah satu bentuk produk olahan kedelai adalah tahu, yang merupakan salah satu produk kedelai yang bersifat non-fermentasi dan telah dikenal di seluruh dunia. Tahu telah menjadi sumber protein dan banyak dikonsumsi di Asia karena harga yang murah dan kandungan protein yang tinggi (Prabhakaran et al., 2006). Tahu merupakan bahan pangan yang bertahan hanya selama satu hari sehingga membutuhkan bahan alami seperti tanpa pengawet (Arianingrum, 2013).

Daun jambu biji memiliki kandungan flavonoid yang sangat tinggi, terutama kuercetin. Senyawa tersebut bermanfaat sebagai anti bakteri, kandungan pada daun jambu biji lainnya seperti saponin, minyak atsiri, tanin, anti mutagenik, flavonoid, dan alkaloid. Daun jambu biji mempunyai banyak manfaat seperti anti mikrobial terhadap Bacillus cereus khususnya pada bakteri gram positif anaerob (Arima dan Danno, 2002 dan Milyani, et al, 2012), anti diare (Ojewole et al, 2008), anti inflamasi dan anti alergi (Baroroh et al, 2015). Setyowati et al, (2014) juga melaporkan bahwa ekstrak daun jambu biji memiliki kemampuan sebagai anti bakteri pada konsentrasi 500-1100 ppm. Daun jambu biji sejak lama digunakan untuk pengobatan secara tradisional dan sudah banyak produk herbal dari sediaan jambu biji. Menurut Sudarsono et al (2002), daun jambu biji mengandung flavonoid, tanin $(17,4 \%)$, fenolat $(575,3 \mathrm{mg} / \mathrm{g}) \mathrm{dan}$ minyak atsiri. Efek farmakologis dari daun jambu biji yaitu anti inflamasi, anti diare, analgesik, anti bakteri, anti diabetes, anti hipertensi dan penambah trombosit. Adapun salah satu senyawa dari flavonoid yang terkandung dalam daun jambu biji adalah kuercetin, yang memiliki titik lebur $310{ }^{\circ} \mathrm{C}$, sehingga kuercetin tahan terhadap pemanasan. Indariani (2006) menunjukkan bahwa ekstrak daun jambu biji yang mempunyai potensi antioksidan terbaik adalah daun jambu biji berdaging buah putih yang diekstrak dengan etanol $70 \%$ secara maserasi.

Mikroorganisme merupakan penyebab utama dalam pembusukan pada tahu, sehingga memperpendek masa simpan. Ekstrak daun jambu yang anti bakteri, diharapkan dapat memperpanjang masa simpan tahu. Tujuan penelitian ini adalah untuk mengetahui pengaruh perendaman daun jambu biji kering terhadap kadar protein, vitamin A dan sensori tahu.

\section{METODOLOGI}

Penelitian ini dilaksanakan pada bulan April-Mei 2019, di Laboratorium pasca panen Balai Pengkajian Teknologi Pertanian Sulawesi Selatan. Bahan dan alat yang digunakan adalah daun jambu biji yang berwarna hijau, kedelai, batu tahu, air bersih, ember, tampah, kain saring, pengaduk, cetakan, keranjang, rak bambu, kompor, blender, peralatan gelas laboratorium, baskom, rotary evaporator, Spektrometer, timbangan digital, Toples kaca, vortexs, bunsen, desikator, Inkubator, Auto clave, Batang pengaduk, Batang L, dan Cawan petri. Rancangan yang digunakan adalah Rancangan Acak Lengkap (RAL) dengan perlakuan lama perendaman yaitu $0,2,4,6,8$ dan 10 hari dengan 3 ulangan. 
Prosedur kerja penelitian ini terbagi atas tiga tahap yaitu :

\section{Pembuatan Tahu (Aryanti et al, 2016)}

Dipilih kedelai yang baik, kemudian dicuci. Kedelai direndam dalam air bersih selama 8 jam (3 liter air per kg kedelai). Kedelai yang telah direndam kemudian dicuci hingga bersih. Kedelai diblender dengan penambahan air hangat sedikit demi sedikit hingga berbentuk bubur (1 bagian kedelai : 2 bagian air hangat). Bubur dimasak sambil diaduk dengan suhu $70-80^{\circ} \mathrm{C}$ (ditandai dengan adanya gelembung-gelembung kecil). Bubur kedelai disaring dan diendapkan airnya dengan menggunakan batu tahu (Kalsium Sulfat $=\mathrm{CaSO}_{4}$, sedikit demi sedikit sambil diaduk perlahan-lahan. Pembuatan larutan koagulan dilakukan berdasarkan metode yang digunakan oleh Sanjay (Sanjay et al., 2008) dengan beberapa modifikasi. Untuk koagulan Kalsium sulfat, digunakan suspensi Kalsium sulfat $\left(\mathrm{CaSO}_{4}\right)$ sebanyak $0.2 \% \mathrm{w} / \mathrm{v}$ dalam $100 \mathrm{ml}$ aquadest. Tahu yang sudah terbentuk dicetak dan dipres hingga hilang sisa airnya.

\section{Pembuatan Simplisia/Ekstrak Daun Jambu Biji}

Penyortiran daun jambu biji, daun jambu biji dicuci dan dibersihkan, kemudian dikeringkan dalam cabinet driyer pada suhu $50^{\circ} \mathrm{C}$. Daun jambu biji yang telah dikeringkan, dihaluskan menggunakan blender sampai daun jambu biji menjadi bubuk (Salmanuddin, et al, 2019).

\section{Perendaman Tahu Dengan Simplisia Daun Jambu}

Pemasakan air hingga mendidih dan didinginkan hingga suhu $80^{\circ} \mathrm{C}$. Penambahan ekstrak kering daun jambu biji sebanyak $20 \mathrm{mg} / 100 \mathrm{ml}$ air panas. Tahu direndam di dalam toples yang sudah berisi ekstrak kering daun jambu biji yang dalam bentuk cairan. Konsentrasi masing-masing perlakuan adalah $20 \mathrm{mg} /$ $100 \mathrm{ml}$ air panas. Tahu direndam dengan air simplisia daun jambu sesuai perlakuan selama 0 hari, 2 hari, 4 hari, 6 hari, 8 hari dan 10 hari.

Untuk mengetahui kualitas tahu yang diperoleh, dilakukan pengujian terhadap kadar protein dan kadar vitamin A (Sudarmadji et.al., 1984) serta uji sensori. Uji sensori yang digunakan adalah metode hedonik (uji kesukaan) terhadap warna, aroma, rasa dan tekstur. Panelis yang digunakan adalah panelis semi terlatih sebanyak 15 orang. Panelis diberikan penjelasan mengenai semua atribut yang akan dinilai untuk menyamakan persepsi sebelum penilaian dilakukan. Penilaian terhadap atribut warna dilakukan secara visual, atribut aroma dinilai dengan cara dicium aromanya, atribut tektur dan rasa dinilai dengan cara memakan tahu yang telah disiapkan, kemudian panelis menulis hasil penilaian di atas kertas dalam bentuk skor. Data ditabulasi dan diolah dengan analisis sidik ragam menggunakan metoda SAS (1999) dan ditampilkan dalam bentuk grafik dan tabel.

\section{HASIL DAN PEMBAHASAN}

\section{Kadar Vitamin A.}

Vitamin A adalah salah satu zat gizi penting yang larut dalam lemak dan disimpan dalam hati, tidak dapat dibuat oleh tubuh sehingga harus dipenuhi dari 
luar (essensial). Vitamin A berfungsi untuk penglihatan dan pertumbuhan dan meningkatkan daya tahan terhadap penyakit (Depkes, 2005).

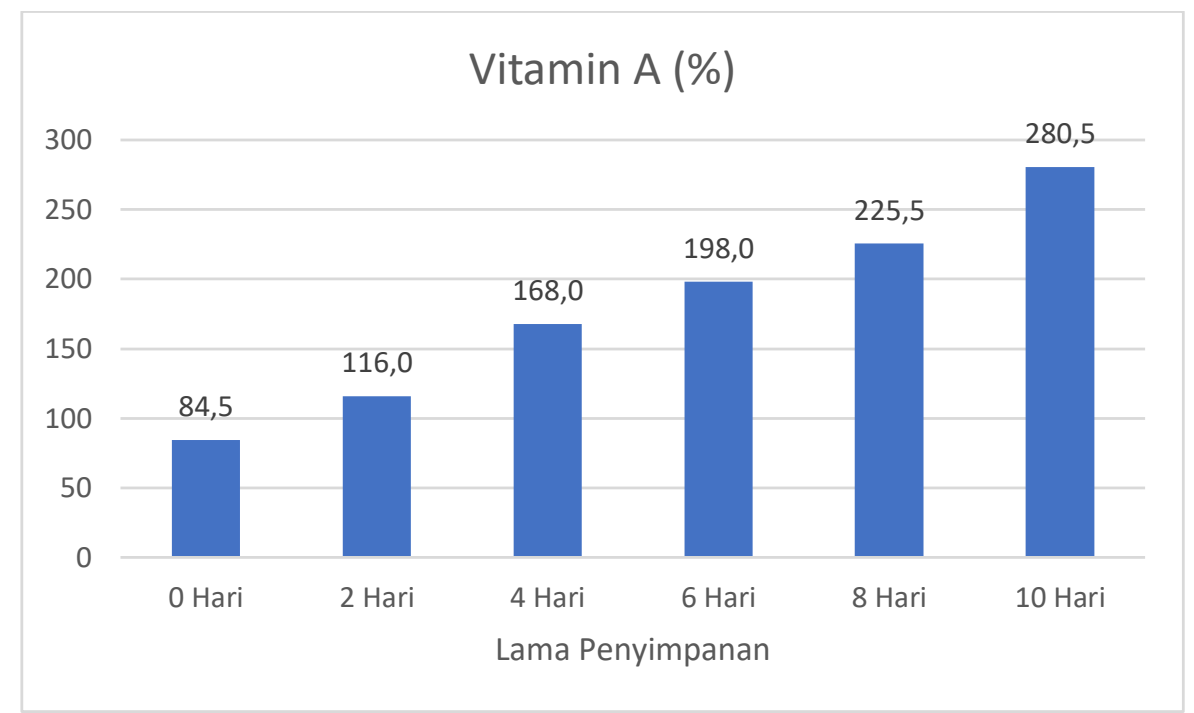

Gambar 1. Hasil pengujian rata-rata vitamin A pada tahu (\%)

Pada Gambar 1 terlihat bahwa kandungan vitamin A tahu tertinggi pada perlakuan perendaman daun jambu biji kering 10 hari $(280,5 \%)$. Dari hasil analisis sidik ragam menunjukkan bahwa perlakuan perendaman daun jambu biji kering terhadap lama simpan berpengaruh nyata terhadap kandungan vitamin A tahu. Semakin lama tahu direndam dengan ekstrak daun jambu biji maka semakin tinggi kandungan vitamin A tahu, pada saat perendaman daun jambu biji 0 hari kandungan vitamin A paling rendah yaitu sebesar 84,5\%, namun kandungan vitamin A semakin meningkat dengan bertambahnya lama perendaman dengan ekstrak daun jambu biji kering. Hal ini diduga karena vitamin A tidak larut dalam air dan tidak mudah teroksidasi, sehingga semakin lama perendaman, vitamin A daun jambu biji semakin tinggi terakumulasi dalam tahu.

Daun jambu biji sudah direkomendasikan sebagai bahan resmi di Departemen Farmasi Belanda. Jambu biji bebas dari lemak dan kolesterol. Daun dan buah jambu juga merupakan sumber serat yang sangat baik, Kalium dan vitamin A (Kamath et al, 2014). Jumlah vitamin A pada daun jambu biji tidak terdeteksi, namun kandungan vitamin $\mathrm{C}$ dan B cukup tinggi masing-masing 103 $\mathrm{mg} / 100 \mathrm{~g}$ dan 14,0 mg/100 gr contoh (Thomas et al, 2017). Sebaliknya buah jambu biji memiliki kandungan vitamin A, lima kali lebih banyak daripada jeruk (Salbiah, 2019).

\section{Kadar protein}

Pada Gambar 2 terlihat pola kadar protein tahu mula-mula rendah pada awal perendaman dan pada perendaman 4 hari dan puncak tertinggi pada perendaman 6 hari $(10,77 \%)$ kemudian menurun dengan semakin lamanya perendaman dan yang terendah kadar proteinnya adalah perlakuan perendaman selama 0 hari $(6.85 \%)$. Namun dari hasil analisis sidik ragam menunjukan bahwa perlakuan perendaman dengan daun jambu biji tidak berpengaruh nyata terhadap kandungan protein tahu atau protein tidak ada perubahan yang nyata 
selama perendaman dengan ekstrak daun jambu biji. Hal ini berarti ekstrak daun jambu biji telah berfungsi sebagai anti bakteri yang hanya mendenaturasi protein bakteri yang berkembang selama perendaman sehngga kandungan protein tahu tidak mengalami perubahan yang nyata.

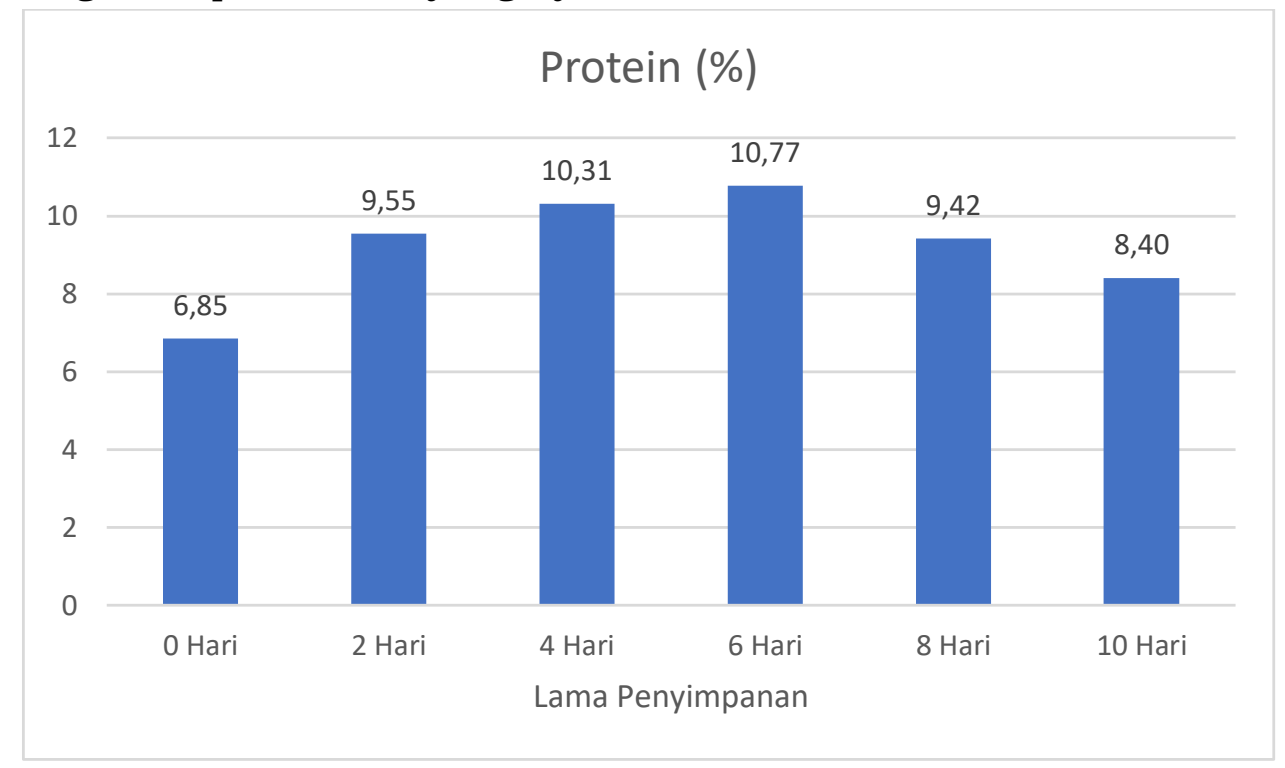

Gambar 2. Hasil pengujian kandungan protein tahu (\%)

\section{Uji sensori}

Hasil uji sensori dapat dilihat pada Tabel 1. Dari hasil analisis statistik diketahui bahwa lama perendaman dalam simplisia daun jambu biji berpengaruh nyata terhadap uji sensori tahu. Semakin lama tahu direndam dalam esktrak daun jambu biji, semakin tidak disukai baik warna, aroma, tekstur dan rasa.

Menurut Nurto'ah (2011), warna suatu produk berhubungan dengan penampakan produk tersebut. Warna dapat digunakan sebagai indikator keseragaman, baik tidaknya cara pencampuran atau cara pengolahan. Secara visual faktor warna yang paling menarik dapat menentukan mutu dari produk. Dipasaran, warna mempengaruhi daya beli konsumen terhadap suatu produk. Oleh karena itu tingkat kesukaan panelis terhadap warna perlu diketahui.

Berdasarkan hasil pengujian warna tahu, panelis paling suka pada warna tahu perlakuan perendaman ekstrak daun jambu biji selama 2 hari dan tidak berbeda nyata dengan perlakuan tahu yang direndam daun jambu biji selama 0 , 4 dan 6 hari, yaitu berwarna putih. Warna pada hari ke 8 hingga ke 10, menjadi warna coklat pudar dan berbeda nyata dengan perlakuan perendaman $0-6$ hari dan warnanya tidak disukai karena panelis belum terbiasa dengan tahu berwarna coklat muda. Semakin lama tahu direndam dalam ekstrak daun jambu, maka warna putih semakin memudar dan berubah menjadi coklat. Perubahan warna tahu yang menjadi lebih gelap pada perlakuan ekstrak daun jambu disebabkan oleh senyawa polifenol yang terdapat pada daun jambu (Qian He \& Nihorimbere, 2004; Adeyemi et al, 2009). Komponen fenolik ini akan teroksidasi dan berkondensasi lebih lanjut menghasilkan komponen dengan berat molekul tinggi yang berwarna coklat (Haard dan Chism, 1994). Lain halnya dengan telur pindang dimana semakin tinggi konsentrasi bubuk 
daun jambu biji yang dipakai semakin tinggi kesukaan panelis terhadap warna telur yang kecoklatan (Salmanuddin et al, 2019). Sehingga ekstrak daun jambu biji bisa juga berfungsi sebagai pewarna alami seperti air daun jambu biji juga dapat memberi warna ikan patin menjadi lebih coklat (Ariyani et al, 2012).

Tabel 1. Pengaruh lama penyimpanan terhadap hasil uji organoleptik hasil perendaman dengan daun jambu biji pada tahu kedelai

\begin{tabular}{ccccc}
\hline Lama perendaman (hari) & Warna & Aroma & Rasa & Tekstur \\
\hline 0 & $2,73 \mathrm{a}$ & $3,13 \mathrm{a}$ & $3,13 \mathrm{a}$ & $3,06 \mathrm{ab}$ \\
2 & $2,93 \mathrm{a}$ & $3,20 \mathrm{a}$ & $3,27 \mathrm{a}$ & $3,20 \mathrm{a}$ \\
4 & $2,67 \mathrm{a}$ & $3,40 \mathrm{a}$ & $3,07 \mathrm{ab}$ & $2,93 \mathrm{ab}$ \\
6 & $2,87 \mathrm{a}$ & $2,73 \mathrm{~b}$ & $2,73 \mathrm{~b}$ & $2,67 \mathrm{bc}$ \\
8 & $2,27 \mathrm{~b}$ & $2,13 \mathrm{c}$ & $2,13 \mathrm{c}$ & $2,40 \mathrm{~cd}$ \\
10 & $2,13 \mathrm{~b}$ & $1,93 \mathrm{c}$ & $1,87 \mathrm{c}$ & $2,20 \mathrm{~d}$ \\
\hline
\end{tabular}

Keterangan : Angka yang diikuti huruf yang sama pada kolom yang sama tidak berbeda nyata pada uji jarak berganda Duncan a =0,05, Skala : (1) sangat tidak suka, (2) tidak suka, (3) agak suka, (4) suka, dan (5) sangat suka.

Rasa merupakan salah satu faktor penentu enak atau tidaknya suatu bahan pangan maupun produk makanan. Suatu bahan pangan maupun produk makanan akan disukai apabila memiliki rasa yang enak dan menarik. Hal tersebut menyebabkan atribut rasa merupakan faktor yang dapat menentukan mutu suatu produk makanan. Rasa yang enak dan menarik suatu produk makanan akan sangat dipengaruhi oleh bahan pangan yang digunakan dalam pembuatan produk makanan (Asmaraningtyas, 2014).

Berdasarkan hasil pengujian tingkat kesukaan perendaman daun jambu biji kering terhadap daya simpan tahu, untuk tingkat kesukaan tertinggi yaitu pada perlakuan perendaman tahu selama 2 hari dengan skor 3,26 tahu yang direndam selama dan tidak berbeda nyata dengan rasa tahu yang direndam ekstrak daun jambu biji selama 0 dan 4 hari. Artinya tahu yang direndam ekstrak daun jambu biji selama 4 hari lebih disukai daripada yang telah direndam $6-10$ hari. Sedangkan tingkat kesukaan terendah pada perlakuan lama perendaman 10 hari dengan skor 2,20 dan tidak berbeda nyata dengan tahu yang direndam selama 8 hari. Tahu yang direndam lebih dari 4 hari tidak disukai rasanya karena rasa yang pahit dan sepat.

Daun jambu biji (Psidium guajava L.) memiliki kandungan senyawa fenol yang cukup banyak diantaranya tanin dan flavonoid, sehingga daun jambu biji bersifat antimikroba (Hermawan, 2012). Daun jambu biji mengandung metabolit sekunder yaitu terdiri dari tannin, polifenol, flavonoid, monoterpenoid, siskulterpen, alkaloid, kuinon dan saponoid, vitamin B1, B2, B3, B6, dan vitamin C (Haji, 2009). Tannin merupakan golongan senyawa fenol yang banyak terdapat pada daun dan termasuk golongan flavonoid dan mempunyai rasa sepat (Robinson, 1995). Senyawa alkaloid secara umum dikenal sebagai golongan tanin yang dihasilkan oleh tumbuh-tumbuhan. Alkaloid mengandung nitrogen dan merupakan turunan dari asam amino yang memiliki rasa pahit dan merupakan metabolit sekunder dari tanaman, hewan dan jamur (Haji, 2009). Sehingga 
semakin lama tahu direndam dengan ekstrak daun jambu biji maka rasanya semakin pahit dan sepat.

Menurut Winarno (2004), aroma yang ditimbulkan dari suatu makanan merupakan faktor penentu kelezatan makanan. Aroma mempunyai peranan yang sangat penting dalam penentuan derajat penilaian dan kualitas suatu bahan pangan. Selain bentuk dan warna, bau atau aroma akan berpengaruh dan menjadi perhatian utama. Setelah aroma diterima maka penentuan selanjutnya adalah cita rasa. Pada Tabel 1 terlihat bahwa tingkat kesukaan aroma tahu tertinggi pada perendaman daun jambu biji kering selama 4 hari dengan skor 3,4 . Tingkat kesukaan paling rendah pada perendaman daun jambu biji kering selama 8 - 10 hari dengan masing-masing skor 2,13 dan 1,93. Rendahnya tingkat aroma tahu pada hari ke 10 karena sudah timbul aroma basi. Menurut Frazier dan Westhoff (1978) bau basi terutama disebabkan oleh aktivitas golongan bakteri koliform dan beberapa spesies bakteri yang dapat menyebabkan pembusukan seperti Clostridium dan Pseudomonas yang menghasilkan bau busuk. Penyimpangan-penyimpangan bau ini terjadi akibat hidrolisis komponen protein dan asam-asam amino secara lanjut yang menghasilkan senyawasenyawa dan gas-gas yang mempunyai citarasa yang tidak disukai. Sehingga efektif perendaman dengan daun jambu biji untuk mendapatkan aroma khas adalah sampai hari ke 6, mulai hari ke 8 aroma tahu menjadi bau busuk.

Tekstur merupakan salah satu komponen terpenting yang menentukan kualitas perendaman tahu (Sari, 2011). Pada Tabel 1 terlihat skor tekstur tertinggi pada perlakuan perendaman tahu dalam ekstrak daun jambu biji kering selama 2 hari dengan skor 3,2 dimana teksturnya lembut dan masih terlihat segar. Hal ini sama dengan penelitian Ariyani et al (2010) bahwa penilaian terhadap atribut tekstur pindang tongkol menunjukkan bahwa pindang tongkol dengan perlakukan penembahan ekstrak daun jambu mempunyai tekstur yang kompak dan hampir tidak berubah selama 2 hari masa penyimpanan. Sedangkan tingkat tekstur paling rendah pada perlakkuan perendaman tahu dalam ekstrak daun jambu biji kering selama 10 hari dengan skor 2,2 dimana tahu sudah rusak dan licin. Selama perendaman, nilai tahu semakin menurun dengan bertambahnya waktu penyimanan. Penyebab tekstur tahu menjadi rusak dikarenakan kadar protein yang tinggi yaitu 10,9 gram per 100 gram tahu (Mahmudah 2008), dan kadar air 70\%-85\% serta aktivitas air 0,98-0,99 maka tahu mudah mengalami pembusukan oleh bakteri pembusuk (Harmayani, et.al. 2009). Setyadi (2008) melaporkan bahwa nilai kecerahan tahu semakin menurun terhadap lamanya waktu penyimpanan. Hal ini disebabkan timbulnya lendir pada permukaan tahu yang menyebabkan kecerahan tahu menjadi berkurang. Pelendiran pada tahu disebabkan oleh bakteri pembentuk lendir terutama dari golongan Pseudomonas, Lactobacillus, dan Streptococcus. Setyadi (2008) juga melaporkan bahwa tahu mudah mengalami proses pelunakan disebabkan oleh aktivitas mikroba bakteri asam laktat yang menyebabkan tekstur tahu menjadi lunak, tidak kompak, dan berlendir. Hal ini berhubungan dengan naiknya kadar air tahu yang disebabkan oleh terurainya komponen-komponen tahu oleh aktivitas bakteri. Proses pelunakan tahu ini memperlihatkan bahwa tahu sudah mengalami kerusakan. 
Pada hari ke 10, ekstrak daun jambu kemungkinan tidak mampu menghalangi aktivitas miktoorganisme maupun enzim penyebab deteriorasi protein pada tahu. Meskipun esktrak daun jambu biji terbukti mempunyai daya hambat terhadap aktivitas bakteri patogen yang pada umumnya merupakan bakteri gram postif seperti S. aureus (Vieira et al, 2001, Goncalves et al, 2008), Shigella dysenteriae dan Salmonella typhi (Adebolu et al, 2007), ekstrak daun jambu biji terbukti tidak mempunyai daya hambat terhadap gram negatif (Sanches et al, 2005) yang umumnya merupakan bakteri pembusuk. Esktrak air daun jambu efektif dalam menghambat aktivitas gram positif (Staphylococcus aureus dan Bacillus subtilis) tetapi tidak efektif dalam menghambat bakteri gram negatif (Escherichia coli dan Pseudomonas aeruginosa). Struktur dinding bakteri gram postif hanya terdiri dari dua lapisan dengan lapisan peptidoglikan yang tebal, sedangkan diding sel bakteri gram negatif terdiri dari 3 lapisan (lipopritein, polisakarida dan peptidoglikan) yang pada membran bagian luarnya terdapat barrier/penahan bagi masuknya jenis antibiotik, sedangkan pada rongga periplasma terdapat enzim yang dapat memecah molukl asing yang datang dari lyar (Beveridge, 1999). Sifat ini yang kemudian menjadikan dinding sel bakteri gram negatif lebih selektif terhadap masuknya senyawa aktif dibandingkan dengan dinding sel bakteri gram positif.

Banyaknya bakteri dalam tahu pada hari ke 10 menyebabkan kerusakan protein yang ada, kerusakan ini akan menghasilkan rasa busuk dan rasa busuk ini akan mempengaruhi rasa tahu. Terbentuknya lendir pada tahu dapat disebabkan oleh aktivitas mikroba antara lain bakteri Bacillus subtilis dan Bacillus mesentericus. Perubahan flavor/rasa biasanya disebabkan oleh mikroba Genus monila, Aspergillus mucor, Alternaria, dan Scopiloriosis, yang menyebabkan bau tidak enak. Sedangkan rasa asam atau basi biasanya disebabkan oleh bakteri pembusuk seperti Coliform, Micrococci dan Achromycetes (Setyadi, 2008). Menurut Frazier dan Westhoff (1978) bau basi terutama disebabkan oleh aktivitas golongan bakteri koliform dan beberapa spesies bakteri yang dapat menyebabkan pembusukan seperti Clostridium dan Pseudomonas menghasilkan bau busuk. Penyimpangan-penyimpangan bau ini terjadi akibat hidrolisis komponen protein dan asam-asam amino secara lanjut yang menghasilkan senyawa-senyawa dan gas-gas yang mempunyai citarasa yang tidak disukai.

\section{KESIMPULAN}

Perendaman tahu ke dalam ekstrak daun jambu biji (Psidium guava L) tidak berpengaruh nyata terhadap kandungan protein tahu dan berpengaruh nyata terhadap kandungan vitamin A dan sensori tahu. Perlakuan terbaik adalah tahu yang direndam dalam ekstrak daun jambu biji selama 4 hari dengan kadar protein 10.31\%, vitamin A 168\%, warna 2,67 (agak suka), aroma 3.4 (agak suka), rasa 3.07 (agak suka) dan tekstur 2.93 (agak suka).

\section{UCAPAN TERIMAKASIH}

Ucapan terima kasih diucapkan kepada Ibu $\mathrm{Hj}$. Ir. Andi Darmawidah yang terlibat langsung dalam pembimbingan selama penelitian ini dan telah memasuki masa purna bakti. 


\section{DAFTAR PUSTAKA}

Adebolu. T.T., Adebove, P. T., and Adegbola, N. B., 2007. Evaluation of A Traditional Decoction Made From Psidium Guajava And Zingiber Aofficinale For Anti Bacterial Activity. Reasearch Journal Of Microbiology, Vol 2 (12) : 854-959.

Adeyemi, Stephen, O., Akanji, M. A., and Aguntove, S.A., 2009. Ethanolic Leaf Extract Of Psidium guajava : Phytochemical and Trypanocidal Activity In Rats Infected with Trypanosoma Brucei. J Med Plant Res, Vol 3 (5) : $420-423$.

Arima, H., and Danno, G., 2002. Isolation of Antimicrobial Compounds From Guava (Psidium giajava L.) and Their Structural Elucidation. Biosience Botechnology and Biochemistry, Vol 66 (8) ; 1727-1730.

Ariyani, F., J.T. Murtini, Gunawan Dan I. Hermana., 2012. Pemanfaatan Ekstrak Air Daun Jambu Biji Sebagai Antioksidan Alami Pada Pengolahan Patin Asin. JPB Perikanan, Vol 7 (1) : 49-60.

Ariyani, J. T., Murtini, dan TH. Sirigear., 2010. Penggunaan Ekstrak Daun Jambu Biji (Psidium guajava $L$ ) sebagai Pengawet Pindang Tongkol. Jurnal Pasca Panen dan Bioteknologi Kelautan dan Perikanan, Vol (5) : 942.

Arianingrum R., 2013. Pemanfaatan Tumbuhan Jambu biji Sebagai Obat Tradisional, Universitas Negeri Yogyakarta, Jogjakarta.

Aryanti N., D. Kurniawati, A. Maharani dan D. H. Wardhani. 2016. Karakteristik Dan Analisis Sensorik Produk Tahu Dengan Koagulan Alami. Jurnal Ilmiah Teknosains, Vol 2 (2).

Asmaraningtyas, D. 2014. Kekerasan, Warna Dan Daya Terima Biskuit Yang Disubstitusi Tepung Labu Kuning. Skripsi. Program Studi Ilmu Gizi, Fakultas Ilmu Kesehatan. Universitas Muhammadiyah Surakarta.

Baroroh HN, Utami ED, Achmad A. 2015. Psidium Guajava Leaves Decrease Arthritic Symptoms In Adjuvant-Induced Arthritic Rats. Universa Medicina, Vol 34(1):169-176.

Beveridge, T.J. 1999. Structure Of Gram Negatif Cell Walls and Their Derived Membrane Vesicles. J. Bacterial, Vol 1818 (16) : 4725-4733.

Depkes, 2005. Vitamin A Berfungsi Untuk Penglihatan Dan Pertumubuhan Dan Meningkatkan Daya Tahan Terhadap Penyakit.

Frazier, W.C. dan D. C. Westhoff. 1978. Food Microbiology. Mc Graw-Hill, Ltd. New York.

Goncalves, F.A., Andrade Neto, M., Bezerra, J.N.S., Macrae, A., De Sousa, OV, Fonteles-Filho, A.A., and Vieira, R.H.S.F., 2008. Antibacterial Activity Of Guava, Psidium guajava Linnaeus, Leaf Extracts On Diarrhea Causin Genteric Bacterial Isolated From Seabob Shrimp Xiphopenaeu kroyeri (Heller). Rest Inst. Med. Trap S. Paulo, Vol 50 (1): 11-15.

Haard, N, and Chism., G. W., 1994. Characteristic Of Edible Plant Tissue. In Fennema, O. R Food Chemistry, 3 ${ }^{\text {rd }}$ Editon. New York Marcel Dekker Inc. P. 943-1001.

Haji, L. A. 2009. Tanaman Obat Tradisonal. Buku Kedokteran EGC 2009. Jakarta 
Harmayani, E. E. S. Rahayu, Titiek F. Djaafar, C. A. Sari, T. Marwati 2009.

Pemanfaatan Kultur Pediococcus acidilactici F-11 Penghasil

Bakteriosin sebagai Penggumpal pada Pembuatan Tahu. Jurnal

Penelitian Pascapanen Pertanian, Vol 6 (1) : 10-20.

Hermawan. 2012. Uji aktifitas Ekstrak Daun Jambu Biji Sebagai Antimikroba

Terhadap Bakteri Karies Streptococcus Mutans Secara In Vitro. Skripi

Malang Universitas Brawijaya. 2012.

Indariani, S.. 2006. Uji Aktivitas Antioksidan Ekstrak Daun Jambu Biji

(Psidium guajava L.). J.II. Pert.Indon, Vol 11 (1).

Kamath J.V. , N. Rahul , C. K. A. Kumar and S. M. Lakshmi. 2014. Psidium guajava L: A review. International Journal of Green Pharmacy, Vol. 2(1): 9 -12 .

Mahmudah. I., 2008. Peningkatan Umur Simpan Tahu Menggunakan Bubuk Kunyit serta Analisa Usaha (Kajian : Lama Perendaman dan Konsentrasi Bubuk Kunyit. Fakultas Teknologi Pangan dan Gizi IPB Bogor.

Milyani, R., 2012. Inhibitory Effect Of Some Plant Extracts On Clinical Isolates

Of Staphylococcus aureus. Afr. J. Microbiol. Res. No. 6 , 6517-6524

Nurto'ah.E.S. 2011. Pengaruh Penambahan Teh Hijau Dan Jahe Instan Terhadap Umur Simpan Susu Skim Dan Susu Penuh Pasteurisasi. Skripsi. Jurusan teknologi Pangan dan Gizi Fakultas Teknologi Pertanian, Institut Pertanian Bogor,Bogor.

Ojewole J, Awe EO, Chiwororo WDH. Antidiarrhoeal Activity of Psidium guajava Linn. (myrtaceae) Leaf Aaqueous Extract in Rodents. J smooth muscle res, Vol 44( 6) :195-207.

Prabhakaran, M. P., Perera, C. O., Valiyaveettil, S., 2006. Effect of Different Coagulants on the Isoflavone Levels and Physical Properties of Prepared Firm Tofu. Food Chemistry, No. 99 : 492-499.

Qian He and Nihormbere, V., 2004. Antioxidant Power oF Phytochemicals From Psidium guajava Leaf. Jounal of Zhejiang University Science, Vol 5 (6) : 676-683.

Salbiah, 2019. 10 Khasiat Minum Rebusan Teh Dauh Jambu Biji Secara Rutin.

Sumber : https://www.jawapos.com/lifestyle/20/01/2019/10-khasiatminum-rebusan-teh-dauh-jambu-biji-secara-rutin/. Akses 11 okt 2019

Salmanuddin, M. Wijaya dan Kadirman. 2019. Daya terima telur pindang dengan penambahan bubuk daun jambu biji (Psidium Guajava Linn). Jurnal Pendidikan Teknologi Pertanian, Vol 5 (1) : $49-55$.

Sanches, N. R., Cortes, D. A. C., Schiavinill, M.S., Nakamaru, CV., and Filho, B.P.D., 2005. An Evaluation of Antibaterial Activities of Psidium guajava (L). Braz Arch Biol Technol, Vol 48 (3) : 429-436.

Sanjay, K. R., Subramanian, R., Senthil, A., Vijayalakshmi, G., 2008. Use of Natural Coagulants of Plant Origin in Production of Soycurd (Tofu). International Journal of Food Engineering, Vol 1 (1) : 1-13.

Sari. 2011. Tekstur Merupakan Salah Satu Komponen Terpenting Yang Menentukan Kualitas Perendaman Tahu.

SAS (Statistical Analysis System). 1999. SAS User's Guide : Statistics SAS Institute, Cary, NC. 
Setyadi,D., 2008. Pengaruh Pencelupan Tahu Dalam Pengawet Asam Organik Terhadap Mutu Sensori Dan Umur Simpan. Fakultas Teknologi Pertanian, Institut Pertanian Bogor. Bogor.

Setyowati E., S. B. Prayitno dan Sarjito., 2014. Pengaruh Perendaman Ekstrak Daun Jambu Biji (Psidium guajava. L) Terhadap Kelulushidupan Dan Histologi Hati Ikan Patin (Pangasius hypophtalamus) yang Diinfeksi Bakteri Edwardsiella Tarda Journal of Aquaculture Management and Technology, Vol 3 (4) : 174-182.

Sudarmadji, S., B. Haryono, dan Suhandi. 1984. Analisis untuk Bahan Makanan dan Pertanian. Edisi II. Bandung: Penerbit Alumni.

Sudarsono, Gunawan, D., Wahyono, S., Donatus, I.A., Purnomo., 2002. Tumbuhan Obat II (Hasil Penelitian, Sifat-sifat dan Penggunaan). Yogyakarta: Pusat Studi Obat Tradisional-Universitas Gadjah Mada.

Thomas, L. Anitha T, Lasyaja AB, Suganya M, Gayathri P, Chithra S., 2017. Biochemical and mineral analysis of the undervalued leaves - Psidium guajava L. International. Journal of Advanced Science and Research, Vol. $2(3): 16-21$.

Vieira, R. H. S. F., Rodrigues, D. P., Goncalves, F. A., Menenzes, F. G. R., Aragao, J. S., and Sauso, O. V., 2001. Microbial Effect of Medicinal Plat Extraxts (Psidium guajava Linn and Gracia papaya Linn) Upon Bacteria Isolated From Fish Muscle and Known to Induce Diarrhea in Children. Res. Inst. Med Trap S. Paulo, Vol 43 (3) : 145-148.

Winarno. 2004. Warna Suatu Bahan Atau Produk Tergantung Oleh Faktor Alam. 